such as the attention being given by the Geophysical Laboratory to thermal measurement and to studies on radioactivity, and by the Department of Terrestrial Magnetism to studies of the earth's crust and of the upper atmosphere as well as to cosmic ray research. A feature of this report is the review of the magnetic survey and observatory programme of the Depart. ment over the period 1904-46. In the Division of Plant Biology, investigations on the chemistry of chlorophyll formation have been extended to include analysis of the process at different temperatures, and in that of Embryology tests have been made of the action of a large series of dyes related to Nile Blue on tumours in mice. Full accounts of work on the organisation of the chromosome, of cryptogenetic studies of maize and Neurospora, of chromosome studies on gall midges, and of work on mouse leukæmia and on the genetic structure of natural populations are included in a long report from the Department of Genetics, while that from the Division of Historical Research deals with the results of the expedition to Bonampak, in Chiapas, Mexico, the field work in the Guatemala highlands and the preparation of a hand-book of ceramic technology for archæologists and a preliminary analysis of Usulatan ware.

\section{INTERNATIONAL COMMITTEE FOR BIRD PRESERVATION}

A MEETING of the European Continental Section of the International Committee for Bird Preservation held in Paris during July 17-20, under the chairmanship of Dr. Boje Benzon, was attended by representatives of Austria, Belgium, Denmark, France, Great Britain, Hungary, Italy, Netherlands, Norway, Sweden and Switzerland; though the German National Section has not yet been reorganised, the interests of that country were repre. sented by the chief game warden of the British Zone accompanied by a German adviser and by a German adviser from the American Zone. The president of the Zoology Section, Intermational Union of Biological Sciences, and an observer from the Natural Sciences Section of Unesco attended, and the Conseil International de la Chasse was also represented.

The chief business of the Conference was the discussion of proposals for the revision of the Paris Convention of 1902 for the Protection of Birds Useful to Agriculture, on which the International Committee for Bird Preservation commenced work thirteen years ago. In 1935 representatives of the Finnish, Norwegian and Swedish Governments drew up a Draft Convention for the International Protection of Birds which was presented at a Conference of the Inter. national Committee for Bird Preservation held in Brussels that year. After due consideration it was decided at this Conference that an entirely new Convention was not practicable and that proposals for the revision of the Paris Convention of 1902 should be put forward. Lord Justice von Seth (Sweden), on behalf of the Scandinavian countries, accepted this suggestion with the proviso that the broad outlines of the Scandinavian proposals should be maintained. The matter was then referred to an International Sub-Committee consisting of $\mathbf{M}$. A. Chappellier (France), (the late) Dr. Percy Lowe (Great Britain), Prof. M. Siedlecki (Poland) and Lord Justice von Seth (Sweden), with Miss Phyllis Barclay.
Smith (Great Britain) and M. Leon Lippens (Belgium) as secretaries. Each national section in Europe was then requested to send to the secretariat suggestions relating to the modification of the Paris Convention. The Sub-Committee, taking into consideration the views of all countries, drew up these suggestions into a general report to serve as a basis for the discussion of a definite final proposal.

The report of the Sub-Committee was discussed at a conference in Vienna in 1937, attended by representatives of twelve European national sections, and proposals for a revision of the Paris Convention agreed. The necessary diplomatic steps to bring these proposals to the attention of the Governments concerned were in progress on the outbreak of war.

However, at a conference held in London in June 1947, attended by representatives of fourteen European national sections, it was decided that in view of the many changed circumstances during ten years, the Vienna proposals were in need of further revision. The matter was again referred to an International Sub-Committee consisting of Dr. Boje Benzon (Denmark), M. G. Olivier (France), Mr. R. A. H. Coombes (Great Britain) and Dr. J. H. Westermann (Netherlands), with Miss Barclay-Smith and M. Lippens as secretaries as before. This Sub-Committee met in Brussels in November 1947 and drew up recommendations which were forwarded to all the national sections of Europe for their comments before being discussed at the Paris Conference in July 1948.

The proposals for the revision of the Paris Convention, 1902, agreed upon at this Conference meet not only the changed conditions and circumstances but also the change in outlook during the course of nearly fifty years. Whereas the Paris Convention was designed to afford protection to birds useful to agriculture (with emphasis on the small insectivorous birds), the scientific, educational and æsthetic aspect of bird life is now recognized, and in point of fact, at the present day, the larger birds are in need of as much, if not more, protection than the small insectivores. Therefore, the fundamental basis of the present proposals is that all birds should have some measure of protection. Far more is known about migration than was the case in 1902, and the countries are becoming more and more aware of their interdependence and obligations towards each other in this matter; it is now appreciated that it is not possible for the country in which migratory birds breed to maintain the stock unaided. The broad outlines of protection now proposed are that birds should be protected during their breeding season and, so far as migratory species are concerned, during the times of their return to their nesting grounds; also that birds in danger of extinction should have special protection. Allowance for exceptions is made when and where necessary in the interests of agriculture, forestry, fishing, science, education, etc., and for the special economic conditions in certain regions. It is also realized that the all-important balance of Nature should be maintained in every way possible, and that any bird which may constitute a menace to other species must be kept in check. The sentimental idea of a 'sanctuary' for all species where everything is inviolate is, in fact, no sanctuary, and there have been far too many instances of this: to take one example, tern colonies have almost disappeared under the onslaught of gulls, to whom an all-embracing 'protection' has afforded an undue advantage. 


\section{No. 4115 September 11, 1948 N A T URE}

Import, export, transport, selling or buying are also dealt with in regard to species taken illegally, and eggs are considered equally with the birds themselves.

Certain methods for the mass capture or destruction of birds are condemned. This is a particularly difficult subject owing to old-established customs and widely diverging points of view and national temperaments. What is regarded as a normal state of affairs in one country may be deplored by its neighbour, and it is not easy to arrive at a general agreement, a tolerant give and take and gradual change being the only solution.

A point which was of no great importance in 1902, but which has become of vital importance in 1948 , is the safeguarding of habitat which is the fundamental for the existence of any species of bird; with the rapid spread of civilization this is becoming more and more serious so far as all forms of wild life are concerned.

In addition to the Convention another important question dealt with by the Paris Conference was the International Inquiry into the status of the Anatidæ in Europe, and the progress being made in the various countries regarding this. The British Section, which has been allocated the task of correlating the information sent in from all over Europe, presented a report on the arrangements being made to carry out this work.

Other matters discussed were the conditions of transport of birds by air, a biological station on the Neusiedlersee in Austria, and the publication of the second edition of an International Ornithological Dictionary by Denmark.

The membership of the International Committee now numbers thirty-five, Iceland having been the latest country to form a national section. The headquarters are at the British Museum (Natural History), London, with further secretariats in Brussels and New York.

\section{BIOLUMINESCENCE}

$\mathrm{T}$ HE increasing use of the fluorescent lamp in recent years has served as a stimulus to the study of the mechanism of the emission of cold light ; and this in turn has led to a renewed interest in the production and utilization of such light in luminous animals. The Section of Biology of the New York Academy of Sciences held a Conference on Bioluminescence in November, 1946, and the papers submitted, which have now been published*, provide a com. prehensive review of the subject.

In a general survey, E. Newton Harvey points out that about forty different orders of plants and animals, ranging from bacteria to fish, contain self-luminous species. A few of these, such as the fish Photo. blepharon and Anomalops, make use of luminous bacteria housed in special pouches which can be covered or exposed at will by a sort of eyelid. Chemiluminescence in genera] is reviewed by $R$. S. Anderson. Colour, fluorescence and chemiluminescence are probably degrees in an analogous process. Emission results from the loss of a quantum of energy during the change from an excited electronic state to a ground-state with less energy, these changes being independent of high temperature. Only in comparatively recent years, with the dis${ }^{1}$ Annals of the New York Academy of Sciences, 49, 327 (1948). covery of the bright chemiluminescence of aminophthalhydrazide and dimethylbiacridinium nitrate, have systems been obtained which can rival in luminosity the substances extracted from living organisms. It was in 1886 that Dubois first demonstrated that light production in animals results from the interaction of luciferin and the enzyme luciferase. In the Ostracod Cypridina these two components are discharged in the form of granules from separate glandular pores and then interact in the sea water. This animal, therefore, affords ideal material for the study of these substances in vitro, and the recent work in this field is reviewed by A. M. Chase. The structure of luciferin has not been fully elucidated; but there is evidence that it has a relatively small molecular weight and contains a hydroxybenzene structure which is reversibly oxidized to a quinone. F. H. Johnson and H. Eyring discuss the action of pressure, temperature and drugs on the enzymes. concerned in bacterial luminescence.

By far the longest paper is by J. B. Buck, who provides a comprehensive review of the anatomy and physiology of the light organ of fireflies and contributes some new suggestions on the control of light emission. There is the utmost diversity in the anatomy of the light organ in the beetles; their histology ranges in complexity from a group of loose independent giant cells, apparently without tracheæ, similar to, and perhaps identical with, the cenocytes (such as occur in Phengodes), to the highly complicated arrangement in Photinus or Luciola where a reflective layer containing urate granules underlies the photo. genic layer. In the most complex type a rich supply of tracheæ runs vertically through the reflective layer and then enters specialized cylindrical rods of tissue which pass straight through the photogenic layer. Here they give off lateral branches which end in conspicuous tracheal end-cells by breaking up into the tracheoles which supply the photogenic cells. Buck is satisfied that the tracheoles do not enter the cells ; but there is evidence that they are connected together by an ultra-tracheolar network which may, perhaps, consist of open tubes.

It is this very highly evolved system which provides some of the most intriguing problems in the physiological control of luminescence. Light may be emitted as a steady glow or in the form of brilliant flashes showing a remarkable periodicity which is under the control of the organism. It is the control of flashing which has excited most controversy. There is no doubt that the organ is supplied by nerves which stimulate it to activity. It is equally sure that the production of light is dependent upon the access of oxygen to the photogenic cells. Argument has centred around the question whether the cells are stimulated directly to produce light-perhaps by the dissolution of barriers which normally separate the enzyme from its substrate- or whether the nerves control the access of oxygen. It is well known that the endings of the tracheoles in many insects contrin liquid which may be absorbed into the tissues during activity and so replaced by air. It has been suggested that the enhanced oxygen supply which then results may be the cause of the light flash; but, as Buck points out, if this change does occur in the tracheoles of the luminous organ it is more likely to be secondary to the metabolic activity of the cells. The tracheal end-cells, an enlarged form of the cells which occur in many insects where the trachex break up into tracheoles, are a characteristic feature of the flashing type of organ. It has often been suggested that they 